\title{
Hypertension in Diabetes Study IV. Therapeutic requirements to maintain tight blood pressure control
}

\section{$H$ ypertension in D iabetes Study G roup}

R adcliffe Infirmary, Oxford, UK

R oyal Infirmary, A berdeen, UK

General H ospital, B irmingham, U K

$\mathrm{H}$ ammersmith H ospital, London, U K

City H ospital, B elfast, U K

R oyal Victoria H ospital, B elfast, U K

St. H elier H ospital, Carshalton, UK

Whittington $\mathrm{H}$ ospital, L ondon, UK

Norfolk and N orwich H ospital, N orwich, UK

L ister H ospital, Stevenage, U K

R eport prepared by I. Stratton, S. M anley, R. H olman, R . Turner
N inewells H ospital, D undee, U K

N orthampton H ospital, N orthampton, U K

Torbay H ospital, Torbay, UK

Peterborough D istrict H ospital, Peterborough, UK

Scarborough H ospital, Scarborough, U K

D erbyshire R oyal Infirmary, D erbyshire, UK

$M$ anchester R oyal Infirmary, M anchester, U K

H ope H ospital, Salford, UK

L eicester G eneral H ospital, L eicester, U K

$\mathrm{R}$ oyal D evon and Exeter Hospital, Exeter, U K
Summary We report the efficacy of therapy over 5 years follow-up in 758 non-insulin-dependent diabetic patients in a prospective, randomised controlled study of therapy of mild hypertension. Patients were recruited who on antihypertensive therapy had systolic blood pressure over $150 \mathrm{mmHg}$ or diastolic over $85 \mathrm{mmHg}$, or if not on therapy had systolic blood pressure over $160 \mathrm{mmHg}$ or diastolic over $90 \mathrm{mmH}$ g. Their mean blood pressure at entry to the study was 160/94 $\mathrm{mmH} \mathrm{g}$ at a mean age of 57 years. They were allocated to tight control (aiming for systolic $<150 /$ diastolic $<85 \mathrm{mmH} \mathrm{g}$ ) or to less tight control (aiming for systolic $<180$ / diastolic $<105 \mathrm{mmH} \mathrm{g}$ ). The tight control group were allocated to primary therapy either with a beta blocker (atenolol) or with an antiotensin converting enzyme inhibitor (captopril), with addition of other agents as required. 0 ver 5 years, the mean blood pressure in the tight control group was significantly lower (143/82 vs $154 / 88 \mathrm{mmH} g, p<0.001$ ). N o difference was seen between those allocated to atenolol or captopril. The proportion of patients requiring three or more antihypertensive therapies to maintain tight control in those allocated to atenolol or captopril increased from 16 and $15 \%$, respectively at 2 years to 25 and
$26 \%$, respectively at 5 years, whereas in the less tight control group at 2 and 5 years only 5 and $7 \%$, respectively required three or more therapies. There was no difference in the incidence of side effects or hypoglycaemic episodes between those allocated to atenolol or captopril, but those allocated to atenolol increased their body weight by a mean of $2.3 \mathrm{~kg}$ compared with $0.5 \mathrm{~kg}$ in those allocated to captopril $(p<0.01)$. A llocation to atenolol was also associated with small increases in triglyceride, and decreases in $L D L$ and HDL cholesterol, which are of uncertain clinical relevance. The study is continuing to determine whether the improved blood pressure control, which was obtained, will be beneficial in maintaining the health of patients by decreasing the incidence of major clinical complications, principally myocardial infarction and strokes, and microvascular complications, such as severe retinopathy requiring photocoagulation and deterioration of renal function. [Diabetologia (1996) 39: 1554-1561]

Keywords Non-insulin-dependent diabetes mellitus, hypertension therapy, angiotensin converting enzyme, beta blocker.
Corresponding author: Hypertension in Diabetes Study Group, Diabetes R esearch Laboratories, Radcliffe I nfirmary, Woodstock R oad, Oxford OX $26 \mathrm{HE}$, UK

Abbreviations: IDDM, Inslin-dependent diabetes mellitus; NID D M, non-insulin-dependent diabetes mellitus; A CE, angiotensin converting enzyme inhibitor; $\mathrm{HDS}, \mathrm{H}$ ypertension in D iabetes Study; U K PD S, U nited K ingdom Prospective D iabetes Study.
In the general population, therapy for moderate or severe hypertension is known to reduce the incidence of strokes and myocardial infarction [1]. R ecent studies have shown that the absolute benefit is more marked in the elderly, since their risk of cardiovascular events is greater than in the general population [2-4]. 
Improved therapy for hypertension in insulin-dependent diabetic (IDDM) patients with reduced glomerular filtration rate reduces the deterioration of renal function $[5,6]$. H owever, no studies have evaluated whether therapy of mild hypertension in non-insulin-dependent diabetic (NIDDM) patients will be clinically advantageous. While this might be assumed, since hypertensive NIDDM patients have an increased incidence of cardiovascular events, patients with hypertension often have other associated risk factors for heart disease including obesity, and raised triglyceride and insulin levels $[7,8]$. Thus, the effect of blood pressure reduction might be less than anticipated, particularly since some therapies have an adverse effect on lipid levels [9, 10]. A s patients with raised urine albumin excretion, termed 'microalbuminuria', have an increased risk of myocardial infarction [11, 12], it is often suggested that they would particularly benefit from reduction of blood pressure, since this reduces albumin excretion [13]. H owever, this may reflect solely renal haemodynamic changes [14] and may not make any difference to the subsequent progression of renal disease or to the associated increased mortality from cardiac disease. In addition, potential side effects of therapy might arise, including an increased risk of hypoglycaemic attacks, since beta blockers can mask the adrenergic symptoms of hypoglycaemia and angiotensin converting enzyme (ACE) inhibitors can increase insulin sensitivity. $O$ ther unsuspected long-term side effects cannot be excluded, as exemplified by recent caution concerning the safety of calcium channel blocking agents [15] and the previously unexpected side-effect of retroperitoneal fibrosis arising from practolol therapy [16].

There is uncertainty as to whether any specific class of antihypertensive therapy may be particularly beneficial. Both beta blockers and A CE inhibitors potentially have specific advantages. Beta blockers are given routinely after myocardial infarction to decrease cardiac mortality [17]. In view of the high incidence of myocardial infarction in hypertensive NIDDM patients, treatment with beta blockers before, rather than after, heart attacks develop might be advantageous. Similarly, A CE inhibitors are a specific therapy for heart failure [18] and produce some reduction in mortality following myocardial infarction [19]. In addition, it has been suggested that A CE inhibitors may have a specific beneficial effect on improving microvascular blood flow as shown by reduction of microalbuminuria in IDDM patients without defined hypertension [20], although such patients still have blood pressure levels slightly higher than control subjects without microalbuminuria. Whether the reduction in urine albumin is a specific effect or is secondary to reduced blood pressure is uncertain, although a study in hypertensive IDDM subjects with renal failure has suggested benefit from A CE inhibitors [21].
The $\mathrm{H}$ ypertension in Diabetes Study (HDS) is a prospective, multicentre study designed to determine whether more intensive therapy of mild hypertension, routinely aiming for blood pressure under 150/ $85 \mathrm{mmHg}$, will be clinically beneficial in patients with NIDDM $[22,23]$. The study includes patients with albuminuria, so it will determine whether patients with increased urine albumin excretion might gain specific benefit or whether treatment of hypertension per se is important.

We report the efficacy of A CE inhibitor and beta blocker therapies and associated side effects over 5 years of follow-up, including the degree to which additional antihypertensive agents are required to maintain improved blood pressure at under $150 \mathrm{mmH} g$ systolic and under $80 \mathrm{mmH} g$ diastolic.

\section{Patients and methods}

Patients recruited into HDS. E ligible hypertensive NIDDM patients in the UK Prospective D iabetes Study (U K PDS) [23] were invited to enter the study between 1987 and 1991. Patients were excluded if they required strict blood pressure control (due to a previous stroke, accelerated hypertension, cardiac or renal failure) or beta blockade (for myocardial infarction in the previous year or current angina), had severe vascular disease (more than one major vascular episode), had a severe concurrent illness or if beta blockade was contraindicated (asthma, intermittent claudication, foot ulcers or amputations). Pregnant women were also excluded.

We recruited 1148 patients on the basis of the mean of blood pressure measurements at three separate clinic visits. We report on the 758 patients who attended the 5 years' follow-up (Table 1). A t randomisation 296 had previously been taking therapy for hypertension, but still had mean blood pressure from three visits above the entry criteria of over $150 \mathrm{mmH}$ g systolic and/or over $85 \mathrm{mmHg}$ diastolic, whereas 462 had previously not been on therapy and had mean blood pressure from three visits above the entry criterion of over $160 \mathrm{mmH}$ g systolic and/or over $90 \mathrm{mmH}$ g diastolic. The two groups had similar blood pressure at entry to the study, 166/93 and $160 / 95 \mathrm{mmH}$ g respectively. O f those previously on therapy $34 \%$ had been taking a beta blocker and $7 \%$ an A CE inhibitor.

B lood pressure measurements. Blood pressure was measured by a trained nurse, with the patient sitting, resting for at least 5 minutes, with the forearm semi-flexed supported on a pillow with the palm facing upwards. M easurements were made with a Copal UA -251 or a Takeda electronic, auscultatory blood pressure reading machine (A ndrew Stephens $C_{0}$., B righouse, West Yorkshire, UK), except for those with obese arms (circumference $>33 \mathrm{~cm}$ ), when a large cuff was used, and in patients with atrial fibrillation, when the blood pressure was measured with a $\mathrm{H}$ awksley random zero sphygmomanometer (H awksley \& Sons L td, L ancing, Sussex, UK ). Diastolic blood pressure was taken as the Korotk off phase 5 . In each patient, four consecutive readings were taken with at least 2-min intervals between readings and the first reading was discarded, while the mean of the last three readings was used in the study if the coefficient of variation was less than $15 \%$. If the coefficient of variation was greater, additional readings were taken until it became less than $15 \%$. For quality assurance, every 
Table 1. Characteristics of patients at entry to the HDS

\begin{tabular}{|c|c|c|c|c|}
\hline & \multicolumn{4}{|c|}{ Previous antihypertension therapy } \\
\hline & A II patients & No & Yes & $\mathrm{p}$ value \\
\hline $\mathrm{n}$ & 758 & 462 & 296 & \\
\hline Gender ( $\%$ male) & 53 & 57 & 47 & $<0.01$ \\
\hline E thnic G roup Caucasian/A sian/A fro-C arribean & $87 / 5 / 8$ & $89 / 5 / 6$ & $86 / 5 / 9$ & NS \\
\hline Systolic BP (mm H g) & $160 \pm 20$ & $160 \pm 18$ & $160 \pm 21$ & NS \\
\hline Diastolic B P (mm H g) & $94 \pm 10$ & $95 \pm 10$ & $93 \pm 10$ & $<0.01$ \\
\hline $\mathrm{HbA}_{1 \mathrm{c}}(\%)$ & $6.8 \pm 1.6$ & $6.8 \pm 1.6$ & $6.8 \pm 1.7$ & NS \\
\hline Fasting plasma glucose $\left(\mathrm{mmol} \mathrm{I^{-1 }}\right)$ & $7.9 \pm 2.6$ & $7.8 \pm 2.6$ & $8.0 \pm 2.5$ & NS \\
\hline Triglyceride $\left(\mathrm{mmol} \mathrm{I}^{-1}\right)^{\mathrm{a}}$ & $1.6(0.9-2.7)$ & $1.5(0.9-2.6)$ & $1.7(1.1-2.8)$ & $<0.01$ \\
\hline Cholesterol $\left(\mathrm{mmol} \mathrm{I}^{-1}\right)$ & $5.5 \pm 1.1$ & $5.5 \pm 1.1$ & $5.5 \pm 1.1$ & NS \\
\hline LDL cholesterol $\left(\mathrm{mmol} \mathrm{I}^{-1}\right)$ & $3.58 \pm 1.11$ & $3.57 \pm 1.12$ & $3.60 \pm 1.10$ & NS \\
\hline HDL cholesterol $\left(\mathrm{mmol} \mathrm{I}^{-1}\right)$ & $1.10 \pm 0.26$ & $1.13 \pm 0.27$ & $1.06 \pm 0.24$ & $<0.001$ \\
\hline
\end{tabular}

Values are mean \pm SD or geometric mean (SD interval)

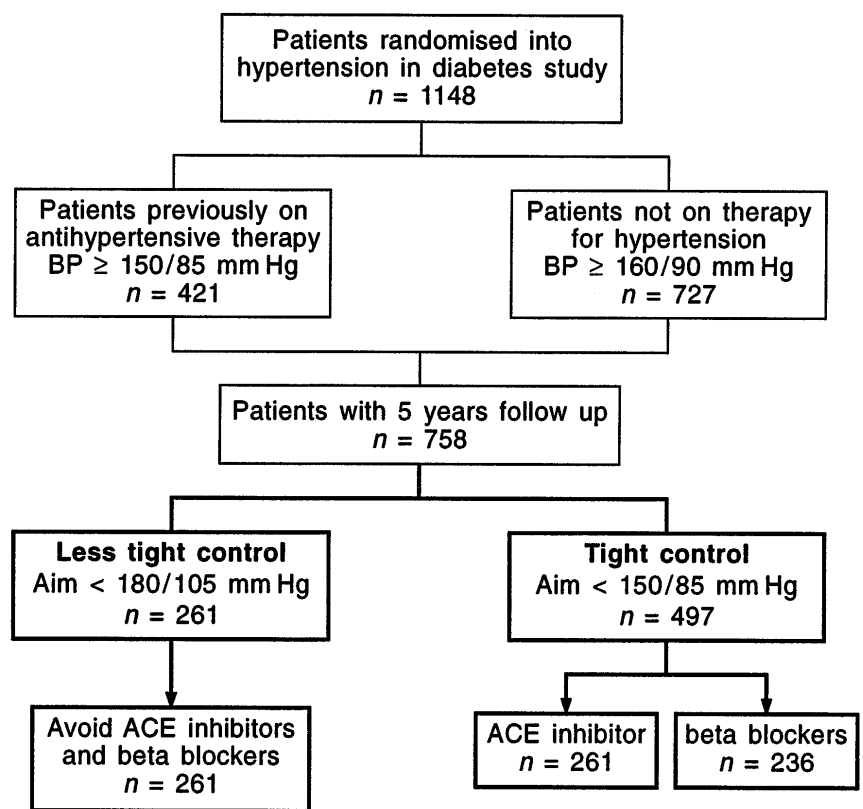

Fig. 1. Flow chart of entry into study and of subjects studied

month blood pressure readings from each automatic machine were compared with a simultaneous random zero sphygmomanometer ( $\mathrm{H}$ awksley) reading. If an absolute systolic or diastolic difference was over $10 \mathrm{mmH} \mathrm{g}$, or a coefficient of variance $10 \%$ or more, additional blood pressure measurements were made. A pparently faulty machines are returned to the central administrative centre for checking repair. The mean difference between Takeda and $\mathrm{H}$ awksley machines has been $1 \mathrm{mmH} \mathrm{g}$ or less, SD $4 \mathrm{mmH}$ g.

Randomisation and therapeutic regimens. Patients were allocated at random to one of three therapeutic groups (Fig. 1). Two thirds of the 1148 patients recruited, 758 patients, were randomised to a tight blood pressure control policy, aiming for blood pressure less than $150 \mathrm{mmH}$ g systolic and $85 \mathrm{mmH} \mathrm{g}$ diastolic. We randomly allocated 400 patients to primary treatment with an ACE inhibitor (captopril) and 358 to primary treatment with a beta blocker (atenolol). O ne third of the patients (390) were allocated to a less tight control group. HDS is in a factorial design with U K PDS and, as would be expected, the allocation to the three HDS therapy groups was statistically independent from eight therapeutic allocations of the UKPD S ( $\chi^{2} 18.0$ on $\left.14 \mathrm{df}, \mathrm{NS}\right)$.

In the 758 patients studied for 5 years, 497 were allocated to tight blood pressure control, 261 to A CE inhibitor and 236 to beta blockers, and 261 to less tight blood pressure control. Initially the aim in the less tight control group was for blood pressure less than $200 / 105 \mathrm{mmH}$ g, but this was modified in 1992 to less than $180 / 105 \mathrm{mmH} g$ by the $\mathrm{D}$ ata M onitoring and $\mathrm{E}$ thics Committee following publication of results of studies of elderly, non-diabetic subjects in the years 1991-1992 [2-4].

In the tight control group captopril was usually started at a dose of $25 \mathrm{mg}$ twice daily, increasing to $50 \mathrm{mg}$ twice daily if required. Diuretic therapy was stopped at least $24 \mathrm{~h}$ before captopril was introduced at a lower dose of $6.25 \mathrm{mg}$ twice daily with observation for $6 \mathrm{~h}$ after the first dose. A tenolol was usually started at a daily dose of $50 \mathrm{mg}$ increasing to a maximum of $100 \mathrm{mg}$ if required.

If control criteria (blood pressure less than $150 \mathrm{mmHg}$ / $85 \mathrm{mmH} \mathrm{g}$ ), were not met in the tight control group despite maximum allocated therapy, additional agents were added, the suggested sequence being frusemide $20 \mathrm{mg}$ daily (maximum $40 \mathrm{mg}$ twice daily), slow release nifedipine $10 \mathrm{mg}$ (maximum $40 \mathrm{mg}$ ) twice daily, methyldopa $250 \mathrm{mg}$ (maximum $500 \mathrm{mg}$ ) twice daily and prazosin $1 \mathrm{mg}$ (maximum $5 \mathrm{mg}$ ) three times daily. Drugs could be stopped if patients experienced side-effects. Physicians were asked not to treat patients allocated to atenolol with A CE inhibitors, and in those allocated to captopril with beta blockers, unless this was required as a last resort in order to reduce the blood pressure to less than $150 /<85 \mathrm{mmH}$ g. In the less tight control group, the same sequence of agents was used if the blood pressure was over $180 \mathrm{mmHg} / 105 \mathrm{mmH}$, avoiding ACE inhibitors and beta blockers if feasible, i.e. therapy initially with frusemide, with additions of slow release nifedipine, methyldopa or prazosin.

Follow-up. Patients were seen every 3 or 4 months at the routine U K PD S clinic visits when blood pressure and fasting plasma glucose were measured and therapies, presence of side effects and history of hypoglycaemic episodes noted. The number of patients who had a minor hypoglycaemic episode (did 
not require medical assistance) or major episodes (required medical assistance or admission to hospital) was assessed each year. The average of five annual assessments was calculated for these patients who remained on their allocated therapy throughout the 5 years. E ach year haemoglobin $A_{1 c}$, fasting plasma triglyceride, HDL - and LDL-cholesterol and urine albumin [24] were measured and every 3 years plasma creatinine, urea, urate and electrolytes.

\section{Statistical analysis}

The data are provided for all subjects who attained 5 years' follow-up with an intention-to-treat analysis irrespective of their current therapies. The exception for side-effects including hypoglycaemic reactions, was an analysis according to those who were taking the appropriate allocated therapy. D ata are expressed as mean and standard deviation, with log transformation of plasma triglyceride. Two tailed t-tests, two-way analysis of variance and $\mathrm{M}$ antel-Haenzel chi-square tests for trend were used and analyses were performed using the Statistical A nalysis System [25]. R esponses over 5 years were assessed by repeat measures analysis of variance, providing mean values from annual visits at 1-5 years, with differences between therapies and changes from baseline data being assessed using the mean of these 5-year values.

Results

Table 1 shows the characteristics of the 758 patients followed for 5 years and Figure 1 shows the flow chart of the study. The patients al ready on antihypertensive therapy at entry into the HDS were slightly older than the untreated patients, with a greater proportion of females. Of the patients at entry $48 \%$ had both raised systolic and diastolic blood pressures, 16\% had only a raised systolic blood pressure and 36\% only a raised diastolic blood pressure. A greater proportion of previously treated patients had both systolic and diastolic raised than in those previously on no therapy, 58 vs $41 \%$ with 15 vs $17 \%$, respectively having only systolic hypertension.

B lood pressure control. The blood pressure responses over 5 years are shown in Figure 2 with baseline and 5-year data in Table 2. In the tight control group the blood pressure fell from the baseline level of 160/ $94 \mathrm{mmH} \mathrm{g}$ to $142 / 83 \mathrm{mmH} g$ at 2 years with no subsequent significant change to $141 / 80 \mathrm{mmH} g$ at 5 years. In the less tight control group the blood pressure fell from $160 / 94 \mathrm{mmHg}$ at entry to $156 / 89 \mathrm{mmHg}$ at 2 years with no subsequent significant change to 154/ $86 \mathrm{mmH} \mathrm{g}$ at 5 years. O ver 5 years, the mean blood pressures in those allocated to tight and less tight groups were $143 / 82$ and $154 / 88 \mathrm{mmH}$ g, respectively $(p<0.0001)$. A t 5 years, a significant blood pressure difference ( $13 \mathrm{mmH} g$ systolic and $6 \mathrm{mmH} g$ diastolic) between the tight and less tight control group was obtained. The blood pressure values achieved in the

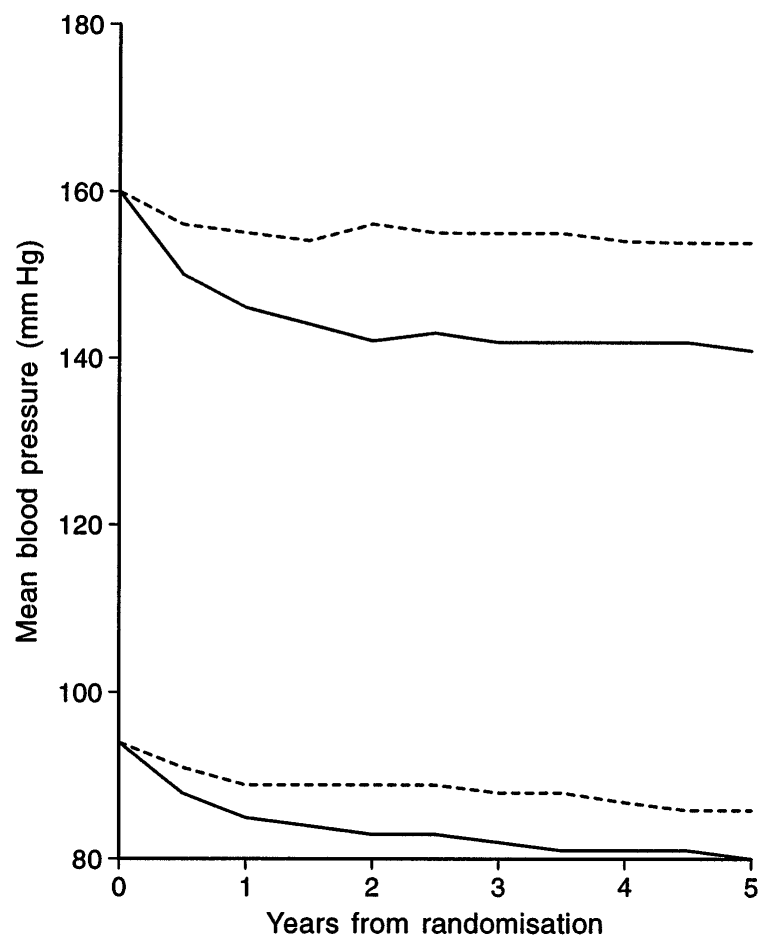

Fig. 2. M ean systolic and diastolic blood pressure in cohort of patients studied over 5 years, 497 allocated to tight control (_--) and 261 to less tight control (----)

Table 2. Blood pressure $(\mathrm{mm} \mathrm{H}$ g) at entry and mean values over 5 years post randomisation according to allocated therapy

\begin{tabular}{lll}
\hline & Pre-treatment & M ean over 5 years \\
\hline Less tight control & $160 \pm 19 / 94 \pm 10$ & $154 \pm 15 / 88 \pm 18$ \\
Tight control & $160 \pm 20 / 94 \pm 10$ & $143 \pm 13 / 82 \pm 7$ \\
Difference $(95 \% \mathrm{Cl})$ & - & $11(9$ to 13$)$ a $/ 6(5 \text { to } 7)^{\mathrm{a}}$ \\
Captopril & $159 \pm 20 / 94 \pm 10$ & $142 \pm 13 / 82 \pm 7$ \\
A tenolol & $161 \pm 20 / 94 \pm 10$ & $143 \pm 13 / 83 \pm 7$ \\
Difference $(95 \% \mathrm{Cl})$ & - & $1(0$ to 4$) / 1(0$ to 2$)$ \\
\hline
\end{tabular}

$\mathrm{D}$ ata are mean \pm SD unless stated otherwise

a $p<0.0001$, tight vs less tight control

atenolol group and in the captopril-treated group over 5 years were similar.

Therapies. Table 3 shows that at 5 years' follow-up of patients not previously taking blood pressure therapy, $69 \%$ of those allocated beta blockers and $80 \%$ allocated to ACE inhibitors were taking the allocated therapy $(p<0.02)$, whereas in those previously on therapy the relevant proportions were similar being 84 and $77 \%$, respectively. Figure 3 shows the increasing proportion of patients that required additional therapies each year with, as expected significantly more subjects allocated to tight control requiring one, two, three or more therapies for less tight control at 5 years $(p<0.0001)$. B y 2 and 5 years 16 and $25 \%$, 
Table 3. A ctual therapies at 5 years and percentage of subjects with blood pressure $150 / 85 \mathrm{~mm} \mathrm{Hg}$ according to randomisation group and treatment status before entry into HDS

\begin{tabular}{|c|c|c|c|c|c|c|}
\hline \multirow[b]{3}{*}{ Previous antihypertensive treatment } & \multicolumn{4}{|c|}{ Tight control } & \multicolumn{2}{|c|}{ Less tight control } \\
\hline & \multicolumn{2}{|c|}{ Captopril } & \multicolumn{2}{|c|}{ A tenolol } & & \\
\hline & No & Yes & No & Yes & No & Yes \\
\hline Blood pressure under $150 / 85 \mathrm{~mm} \mathrm{H} \mathrm{g}$ at 5 years (\%) & 50 & 46 & 60 & 58 & 25 & 19 \\
\hline B eta blocker (\%) & 3 & 13 & 69 & 84 & 8 & 10 \\
\hline A CE inhibitor & 80 & 77 & 3 & 10 & 11 & 16 \\
\hline $\begin{array}{l}\text { On maximum dose of allocated therapy (\%) } \\
\text { (\% of those on allocated therapy) }\end{array}$ & 70 & 78 & 75 & 89 & NA & NA \\
\hline $\begin{array}{l}\text { On allocated therapy alone (\%) } \\
\text { plus one other } \\
\text { plus two others } \\
\text { plus three others }\end{array}$ & $\begin{array}{r}29 \\
33 \\
16 \\
2\end{array}$ & $\begin{array}{r}13 \\
29 \\
28 \\
7\end{array}$ & $\begin{array}{r}26 \\
28 \\
14 \\
1\end{array}$ & $\begin{array}{r}4 \\
44 \\
32 \\
4\end{array}$ & $\begin{array}{r}52^{\mathrm{a}} \\
34^{\mathrm{b}} \\
10^{\mathrm{c}} \\
4^{\mathrm{d}}\end{array}$ & $\begin{array}{l}25^{\mathrm{a}} \\
40^{\mathrm{b}} \\
24^{\mathrm{c}} \\
11^{\mathrm{d}}\end{array}$ \\
\hline Not on antihypertensive therapy & 7 & 0 & 12 & 2 & 52 & 25 \\
\hline On diuretics (\%) & 43 & 61 & 36 & 52 & 21 & 35 \\
\hline
\end{tabular}

${ }^{a} \mathrm{O} n$ no antihypertensive agents; ${ }^{\mathrm{b}}$ on one agent; ${ }^{\mathrm{c}}$ on two agents;

$R$ esults as percentage of patients allocated

${ }^{d}$ on three agents or more

NA, Not allocated

respectively, of those allocated to atenolol were taking three or more drugs and similarly 15 and $26 \%$, respectively, of those allocated to an ACE inhibitor were taking three or more drugs, compared with 5 and $7 \%$, respectively, in those allocated to less tight control. 0 ver the first 2 years the increased number of therapies was associated with slightly better blood pressure control, but from 2 years onwards there was no significant change in the blood pressure control. Fewer patients allocated to less tight control required additional therapies, but the same trend for an increasing proportion requiring more therapies was apparent (Fig. 3).

The blood pressure control at 5 years was similar in those who required the allocated therapy or an additional one or two other agents. For those allocated to captopril and atenolol, the mean blood pressures in those taking only the allocated therapy were 138/ 79 and $137 / 78 \mathrm{mmH} \mathrm{g}$, respectively; with one additional agent $142 / 80$ and $141 / 80 \mathrm{mmH} \mathrm{g}$, respectively; and on two or more additional agents 140/80 and $140 / 80 \mathrm{mmH} \mathrm{g}$, respectively. This indicates that the physicians were heeding the study's control criteria viz, they were aiming for under $150 / 85 \mathrm{mmH} g$ and adding additional therapies to achieve that aim, irrespective of how many agents the patients were taking.

Side effects. Table 4 shows that those allocated to atenolol had a mean increase in body weight of $2.3 \mathrm{~kg}$ compared with $0.5 \mathrm{~kg}$ in those allocated to captopril $(p<0.0001)$ and $1.2 \mathrm{~kg}$ in those allocated to less tight control. A mean increase in fasting plasma glucose of $\left.1.0 \mathrm{mmol} \cdot\right|^{-1}$ in those allocated to atenolol, was greater than an increase of $0.7 \mathrm{mmol} \cdot \mathrm{I}^{-1}$ with captopril $(p<0.01)$, although a similar trend in haemoglobin $A_{1 c}$ was not significantly different. Those allocated to atenolol had a marginally greater increase
Randomised to captopril

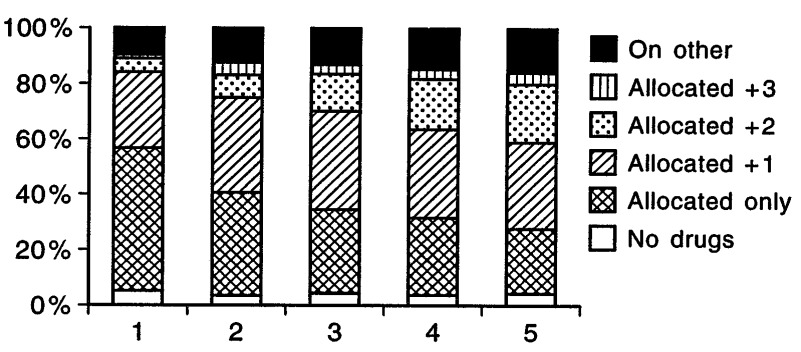

Randomised to atenolol

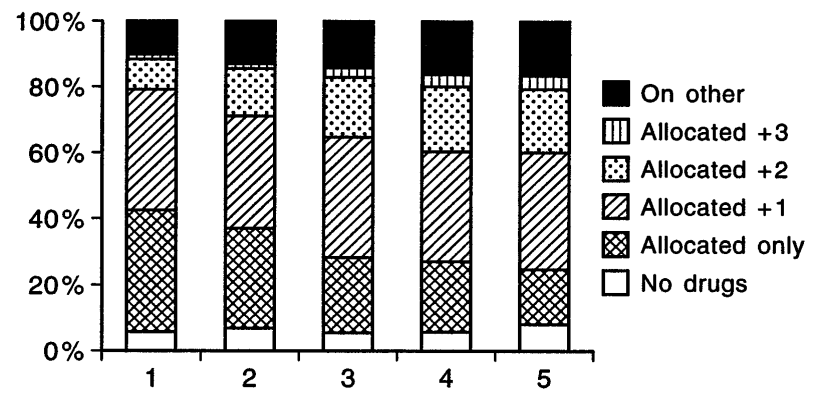

Randomised to less tight control

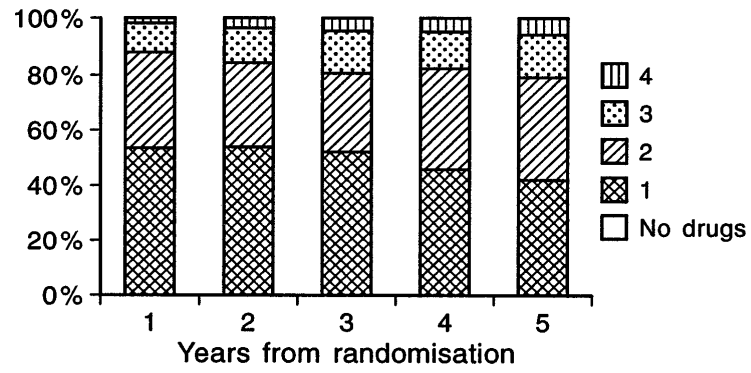

Fig. 3. Proportion of patients allocated to less tight control and tight control with atenolol or captopril taking different numbers of drugs 
Table 4. Changes from baseline to mean values over 5 years for body mass index, fasting plasma glucose, triglyceride, LDL and HDL cholesterol in subjects by allocated therapy

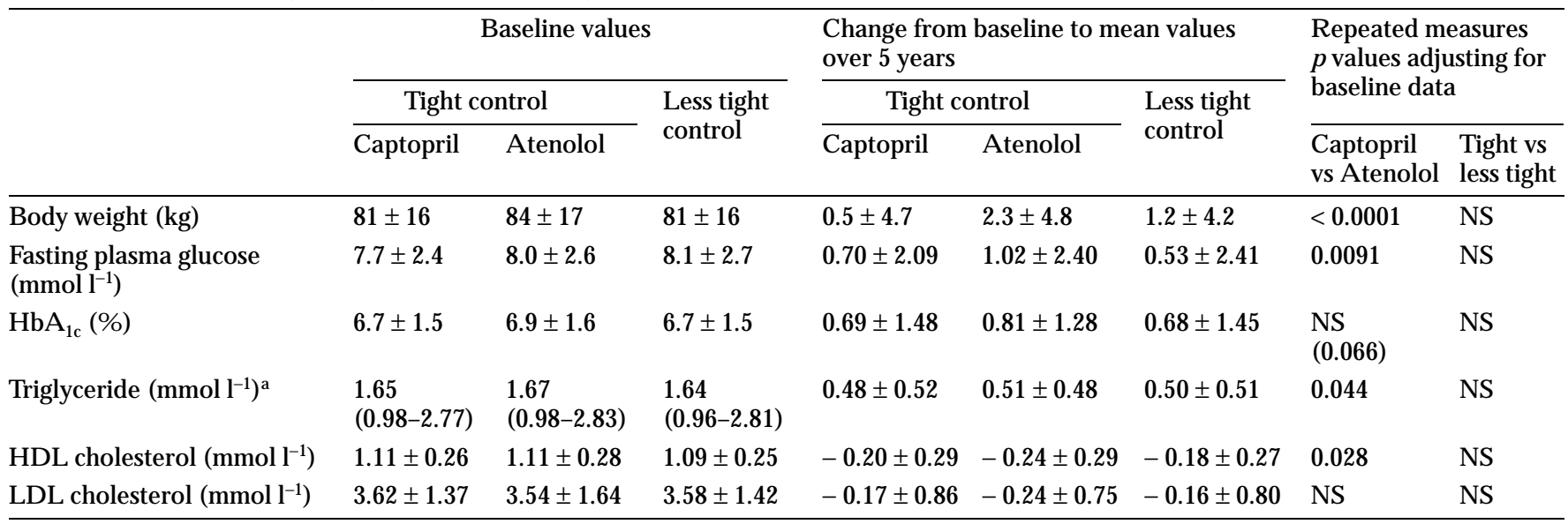

Values are mean \pm SD or geometric mean (SD interval)

Table 5. A nnual rates of hypoglycaemic episodes over 5 years in subjects who took allocated therapy

\begin{tabular}{|c|c|c|c|c|c|c|}
\hline \multirow[t]{3}{*}{ Time post randomisation } & \multicolumn{3}{|c|}{ A ny hypoglycaemic episode } & \multicolumn{3}{|c|}{ M ajor hypoglycaemic episode } \\
\hline & \multicolumn{2}{|c|}{ Tight control } & \multirow{2}{*}{$\begin{array}{l}\text { Less tight } \\
\text { control }\end{array}$} & \multicolumn{2}{|c|}{ Tight control } & \multirow{2}{*}{$\begin{array}{l}\text { Less tight } \\
\text { control }\end{array}$} \\
\hline & Captopril & A tenolol & & Captropril & A tenolol & \\
\hline $\begin{array}{l}\text { n } \\
\text { 1st year } \\
\text { 2nd year } \\
\text { 3rd year } \\
\text { 4th year } \\
\text { 5th year } \\
\text { E ver over } 5 \text { years }\end{array}$ & $\begin{array}{l}247 \\
16 \% \\
19 \% \\
20 \% \\
22 \% \\
24 \% \\
38 \%\end{array}$ & $\begin{array}{l}223 \\
14 \% \\
20 \% \\
23 \% \\
25 \% \\
22 \% \\
40 \%\end{array}$ & $\begin{array}{l}258 \\
17 \% \\
16 \% \\
18 \% \\
18 \% \\
21 \% \\
40 \%\end{array}$ & $\begin{array}{l}247 \\
2.5 \% \\
0.9 \% \\
0 \\
1.0 \% \\
0.5 \% \\
4.0 \%\end{array}$ & $\begin{array}{l}223 \\
0.5 \% \\
1.0 \% \\
1.0 \% \\
3.1 \% \\
1.6 \% \\
4.9 \%\end{array}$ & $\begin{array}{l}228 \\
0.8 \% \\
0.4 \% \\
0.8 \% \\
0.9 \% \\
1.8 \% \\
3.1 \%\end{array}$ \\
\hline
\end{tabular}

No significant differences were found between the randomisation groups either by chi-squared test or Fisher's exact test

in triglyceride and reduction of HDL cholesterol than those allocated to captopril (Table 4).

Table 5 shows there was no significant difference between allocations in the proportion of patients having hypoglycaemic episodes, when analysing those who remained on their allocated therapy. The data analysed on an intention-to-treat basis were similar.

A t each visit, patients were asked to report any symptoms. The only difference between tight control and less tight control was 41 and $31 \%(p<0.01)$, respectively who said they had nausea or dyspepsia, with no significant difference between those allocated to captopril and atenolol. No difference was observed for other symptoms including tiredness, depression, or being peripherally cold.

Plasma electrolytes. A t 5 years there were no significant differences in plasma electrolytes between therapy allocation (Table 6). Those taking diuretic therapy had lower mean potassium values, with a greater proportion having potassium values under $3.5 \mathrm{mmol}$. $1^{-1}$. Those taking captopril had similar potassium values to those taking atenolol, with both therapies being associated with a greater proportion with potassium values over $5.0 \mathrm{mmol} \cdot \mathrm{I}^{-1}$.

\section{Discussion}

The study has shown that in NIDDM patients with mild hypertension, improved blood pressure control can be maintained over 5 years. The patients, mean age 62 years, had a mean blood pressure over 5 years of $143 / 82 \mathrm{mmH} g$ in those allocated to tight control, compared with $154 / 88 \mathrm{mmH} g$ in those allocated to less tight control. In practice, physicians often accept blood pressure control similar to that observed in the less tight control group. If the study finds that aiming for blood pressure under $150 / 85 \mathrm{mmH} g$ is clinically advantageous, greater emphasis on improving blood pressure control would be required.

Therapy with atenolol or captopril induced similar blood pressure lowering efficacy, with a similar proportion of patients attaining the required blood pressure control with atenolol or captopril alone, and a similar proportion requiring additional therapies. In those allocated to tight control by 5 years' follow-up, $25 \%$ were requiring three or more different agents. In addition, there was a continuing trend for an increasing proportion of patients requiring additional agents. Thus, as for blood glucose therapy, if improved blood pressure control is shown to be 
Table 6. Plasma electrolytes, by allocation and in those taking A CE inhibitor, beta blockers, or diuretics

\begin{tabular}{|c|c|c|c|c|c|c|}
\hline & $n$ & $\begin{array}{l}\text { Sodium } \\
(\mu \mathrm{mol} / \mathrm{l})\end{array}$ & $\begin{array}{l}\text { Potassium } \\
(\mathrm{mE} \mathrm{q} / \mathrm{l})\end{array}$ & $\begin{array}{l}\mathrm{K}^{+}<3.5 \\
(\%)\end{array}$ & $\begin{array}{l}\mathrm{K}^{+}>5.0 \\
(\%)\end{array}$ & $\begin{array}{l}\text { B icarbonate } \\
(\mathrm{mE} \mathrm{q} / \mathrm{l})\end{array}$ \\
\hline \multicolumn{7}{|l|}{ By allocation } \\
\hline Less tight control & 235 & $140.3 \pm 2.8$ & $4.20 \pm 0.46$ & $3 \%$ & $6 \%$ & $26.2 \pm 3.7$ \\
\hline A tenolol & 215 & $140.3 \pm 2.6$ & $4.30 \pm 0.42$ & $1 \%$ & $6 \%$ & $26.2 \pm 3.5$ \\
\hline \multicolumn{7}{|l|}{ By therapy } \\
\hline $\begin{array}{l}\text { A llocated to captopril } \\
\text { taking captopril } \\
\text { and taking diuretic }\end{array}$ & $\begin{array}{l}89 \\
93\end{array}$ & $\begin{array}{l}140.1 \pm 3.2 \\
140.7 \pm 3.0 \\
\text { NS }\end{array}$ & $\begin{array}{l}4.35 \pm 0.45 \\
4.20 \pm 0.44 \\
p<0.05\end{array}$ & $\begin{array}{l}1 \% \\
3 \%\end{array}$ & $\begin{array}{l}8 \% \\
4 \%\end{array}$ & $\begin{array}{l}26.1 \pm 3.3 \\
26.7 \pm 3.6\end{array}$ \\
\hline
\end{tabular}

D ata are mean $\pm S D$

beneficial, continued review of whether additional therapy is required will be necessary. The blood pressure control was similar in those allocated to tight control who were taking monotherapy, and one or more additional therapies. This indicates that when the control criteria of aiming for under 150/ $85 \mathrm{mmH} g$ was set, it was generally feasible for physicians to add additional therapies to meet these criteria.

The proportion of patients experiencing symptoms over 5 years was similar in those allocated to captopril and atenolol. By this time, patients with recognised specific side effects such as cough or cold legs, had been changed to other therapies [22]. The symptom questionnaire showed no continuing unexpected symptoms between allocation to atenolol and captopril, although $41 \%$ of those allocated to tight control reported nausea/dyspepsia compared with $31 \%$ in the less tight control group with no difference between atenolol and captopril therapies. Those allocated to atenolol had a mean $1.8 \mathrm{~kg}$ greater increase in weight compared with those allocated to captopril, in keeping with other studies [26]. They also had a greater increase of $0.3 \mathrm{mmol} / \mathrm{l}$ plasma triglyceride compared with captopril, confirming the analysis after 2 years' therapy. Whether these aspects of therapy with atenolol will have any associated disadvantages is not known, but prospective studies of therapy of hypertension and angina have shown benefit from beta blocker therapy. These were predominantly with non-selective beta blockers, and it is not known whether similar benefit would be obtained from selective beta blockers [27].

Therapy with A CE inhibitors is known to be associated with increased plasma potassium levels, but there was no difference between those treated with captopril or atenolol. Diuretics are known to decrease the potassium concentrations and this occurred irrespective of other therapies. It is not known whether the minor differences are of clinical significance.

If HDS shows that improved blood pressure control is advantageous, it would mean that more than $50 \%$ of diabetic patients in their sixth decade would require therapy for hypertension and that approximately $25 \%$ of these would use three or more drugs. The study will evaluate whether beta blockers (which are relatively inexpensive) or A CE inhibitor therapy have any specific advantages or disadvantages, both in terms of prevention of major clinical complications and in the progress of subclinical variables assessing the progress of macrovascular or microvascular disease.

A cknowledgements. The helpful collaboration of patients, staff and N H S Trusts at each centre is appreciated. The study is funded by Medical R esearch Council, B ristol Myers Squibb, D epartment of $\mathrm{H}$ ealth, B ritish $\mathrm{H}$ eart Foundation, $\mathrm{N}$ ational $\mathrm{E}$ ye Institute, $\mathrm{N}$ ational Institutes of $\mathrm{H}$ ealth, $\mathrm{B}$ ritish $\mathrm{D}$ iabetic $\mathrm{A}$ ssociation, National Institute of Digestive, D iabetic and Kidney Disease, NIH. The manuscript was prepared by M S. I. Samuel and M s. C. Wood.

Prepared for publication by: I.M.Stratton, S.E.M anley, R.R.H olman, R.C.Turner

\section{References}

1. Collins R, Peto R, M acM ahon S et al. (1990) Blood pressure, stroke, and coronary heart disease: Part 2, short-term reductions in blood pressure: overview of randomised drug trials in their epidemiological context. L ancet 335: 827-838

2. MRC Working Party (1992) Medical Research Council trial of treatment of hypertension in older adults: principal results. B M J 304: 405-412 
3. SHE P Cooperative R esearch G roup (1991) Prevention of stroke by antihypertensive drug treatment in older persons with isolated systolic hypertension. Final results of the Systolic $\mathrm{H}$ ypertension in the E Iderly Program (SH E P). J A M A 265: 3255-3264

4. D ahlöf $B$, L indholm $L$, H ansson $L$, Schersten $B, E$ kbom $T$, Wester PO (1991) M orbidity and mortality in the Swedish trial in old patients with hypertension (STOP-H ypertension). L ancet 338: 1281-1285

5. Parving $\mathrm{H}-\mathrm{H}, \mathrm{A}$ nderson $A \mathrm{R}$, Smidt U M , H ommel E, M athiesen E R , Svendsen PA (1987) E ffect of antihypertensive treatment on kidney function in diabetic nephropathy. BJ M 294: 1443-1447

6. Mogensen CE (1989) The effect of blood pressure intervention on renal function in insulin-dependent diabetes. D iabète M etab 15: 343-351

7. The H ypertension in D iabetes Study G roup (1993) H ypertension in D iabetes Study I: prevalence of hypertension in newly presenting type 2 diabetic patients and the association with risk factors for cardiovascular and diabetic complications. J H ypertens 11: 309-317

8. Stern M P, H affner SM (1991) D yslipidemia in type 2 diabetes - implications for therapeutic intervention. Diabetes Care 14: 1144-1159

9. R oberts WC (1989) R ecent studies on the effects of beta blockers on blood lipid levels. A m H eart J 117: 709-714

10. Pollare T, Lithell H, Selinus J, B erne C (1989) Sensitivity to insulin during treatment with atenolol and propanolol: a randomised, double blind study of effects on carbohydrate and lipoprotein metabolism in hypertensive patients. B M J 298: 1152-1157

11. Jarrett RJ, Viberti G C, A rgyropoulos A , H ill R D, M ahmud U, M urrells TJ (1984) M icroalbuminuria predicts mortality in non-insulin dependent diabetes. Diabet M ed 1: 17-19

12. Mogensen CE (1984) Microalbuminuria predicts clinical proteinuria and early mortality in maturity-onset diabetes. N Engl J Med 310: 356-360

13. M ogensen CE, K eane WF, B ennett PH et al. (1995) Prevention of diabetic renal disease with special reference to microalbuminuria. L ancet 346: 1080-1084

14. M ogensen CE (1995) D iabetic renal disease: the quest for normotension - and beyond. D iabet M ed 12: 756- 769

15. Y usuf S (1995) Calcium antagonists in coronary artery disease and hypertension: time for re-evaluation? Circulation 92: 1079-1082
16. B rown P, B addeley $H$, R eade A E, D avies J D, M CG arry J (1974) Sclerosing peritonitis, an unusual reaction to a beta-adrenergic-blocking drug (practolol). Lancet II: 1477-1481

17. Y usuf S, Peto R, L ewis J, Collins R, Sleight P (1985) Beta blockade during and after myocardial infarction: an overview of the randomised trials. Prog Cardiovasc Dis 27: 335-371

18. Pfeffer M A , B raunwald $E, M$ oyé $L A$ et al. (1992) E ffect of captopril on mortality and morbidity in patients with left ventricular dysfunction after myocardial infarction. R esults of the Survival and Ventricular E nlargement Trial. N E ngl J M ed 327: 669-677

19. ISI S-4 (Fourth International Study of Infarct Survival) Collaborative Group (1995) A randomised factorial trial assessing early oral captopril, oral mononitrate, and intravenous magnesium sulphate in 58,050 patients with suspected acute myocardial infarction. L ancet 345: 669-685

20. Mathiesen ER, Hommel E, G iese J, Parving H-H (1991) E fficacy of captopril in postponing nephropathy in normotensive insulin dependent diabetic patients with microal buminuria. BMJ 303: 81-87

21. Lewis EJ, H unsicker LG, B ain R P, R ohde R D (1993) The effect of angiotensin-converting-enzyme inhibition on diabetic nephropathy. Eng J M ed 329: 1456-1462

22. Hypertension in Diabetes Study Group. HDS III (1994) Prospective study of therapy of hypertension in type 2 diabetic patients: efficacy of A CE inhibition and beta-blockade. Diabet $M$ ed 11: 773-782

23. UK Prospective Diabetes Study Group (1991) UKPDS VIII. Study design, progress and performance. Diabetologia 34: 877-890

24. U K Prospective D iabetes Study G roup (1994) U K PD S XI: B iochemical risk factors in type 2 diabetic patients at diagnosis compared with age-matched normal subjects. D iabet M ed 11: 534-544

25. SA S Institute (1990) Statistical A nalysis System, Version 6. Cary, N orth Carolina, U SA :SA S I nstitute

26. R össner S, Taylor CR, Byington R P, Furberg CD (1990) Long term propanolol treatment and changes in body weight after myocardial infarction. B MJ 300: 902-903

27. B rown MJ (1995) To $\beta$ block or better block? - $\beta_{1}$ selectivity rarely matters in clinical practice despite the hype. B MJ 311: 701-702 